\title{
Thrust-fault architecture of glaciotectonic complexes in Denmark
}

\author{
Stig A. Schack Pedersen and Lars Ole Boldreel
}

Cross sections of glaciotectonic complexes are exposed in coastal cliffs in Denmark, which allow structural studies of the architecture of thin-skinned thrust-fault deformation (Pedersen 2014). However, the basal part of the thrust-fault complex is never exposed, because it is located 50 to $100 \mathrm{~m}$ below sea level. It is in the basal part the most important structure - the décollement zone - of the complex is found. The décollement zone constitutes the more or less horizontal surface that separates undeformed bedrock from the displaced thrust-sheet units along the décollement level. One of the most famous exposures of glaciotectonic deformations in Denmark is the Møns Klint Glaciotectonic Complex. The structures above sea level are well documented, whereas the structures below sea level down to the décollement level are poorly known. Modelling of deep structures was carried out by Pedersen (2000) but still needs documentation.

A glaciotectonic complex affecting comparable rock units, such as the chalk at Møns Klint, was recently recognised in seismic sections from Jammerbugten in the North Sea (Fig. 1). These sections provide an excellent opportunity for comparable studies of the upper and lower structural levels in thin-skinned thrust-fault deformation, which is discussed in this paper with examples from three major glaciotectonic complexes.

\section{Architecture of thrust-fault deformations in glaciotectonic complexes}

In contrast to fold-belt ranges, glaciotectonic complexes are relatively small and therefore easier to study. For these structural complexes, an architectural classification was defined based on description and ordering of surfaces and their relations (Pedersen 2014). It is emphasised that the creation of constructions comprising surfaces is the basic element of their architecture. In geology the use of architectural analysis is well known in investigations of sedimentary deposits. A concept for ordering of bounding surfaces in the architecture of aeolian dunes was suggested by Brookfield (1977), and a similar concept was suggested by Miall (1985) for facies analysis of fluvial deposits.

For the analysis of glacial architecture and construction of $3 \mathrm{D}$ geological models of glaciotectonic complexes the clas- sification of a hierarchy of bounding surfaces comprises four orders of surfaces (Pedersen 2014). The décollement surface is defined as a first-order surface (Fig. 2). The décollement surface is the 'base' of the complex, and therefore the top of the complex also has to be defined as a first-order surface. This second first-order surface is the topographic top of the tectonic complex, or alternatively, a truncating unconformity, above which post-deformational units occur.

The internal framework of a tectonic complex comprises thrust sheets. These are bounded by thrust faults, which are defined as second-order surfaces (Fig. 2). The thrust faults are differentiated into ramps and flats, where a ramp cross-cuts the bedding, whereas the flat is more or less bedding-parallel. When two or more thrust sheets are bounded by ramps and flats they form duplexes. These generally form imbricate complexes or may be stacked so they form complex repetitions of the geological units (as exemplified by Pedersen 2005).

The folded beds comprise third-order surfaces. These are differentiated into anticlines, synclines, recumbent folds and monoclinal bends. Folds may further be classified from the

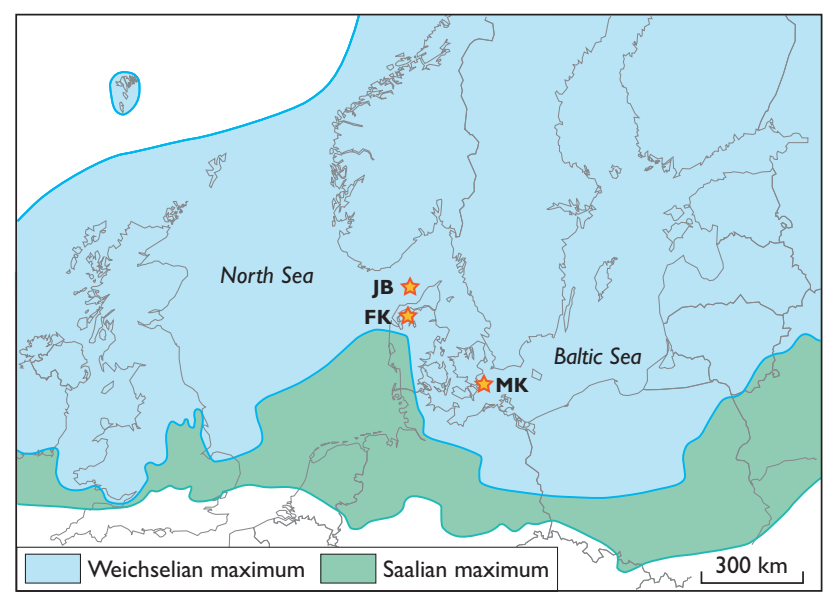

Fig 1. Extent of ice sheets during the two last glaciations and the location of the three glaciotectonic complexes mentioned in this paper. JB: The Jammerbugt Glaciotectonic Complex was formed by an ice advance from central Scandinavia during the Saalian. FK: The Fur Knudeklint Glaciotectonic Complex was formed during an ice advance from Norway during the Late Weichselian. MK: The Møns Klint Glaciotectonic Complex is exposed in a coastal cliff by the Baltic Sea, and it was formed during the latest part of the Weichselian. 


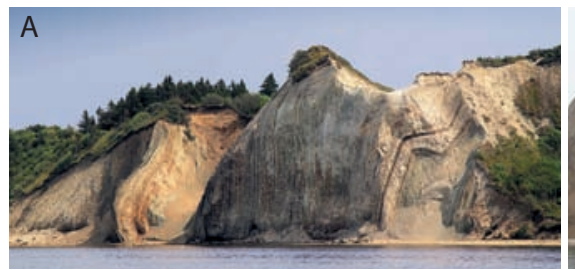

B

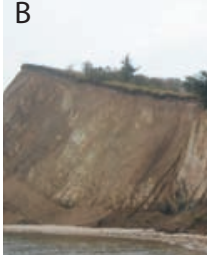

C North

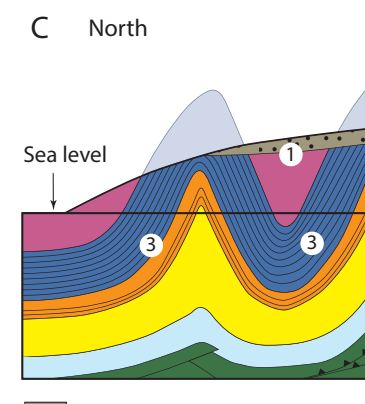

Glacial deposits

Røsnæs Clay Formation

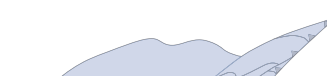

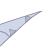
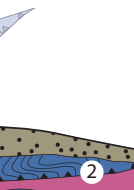

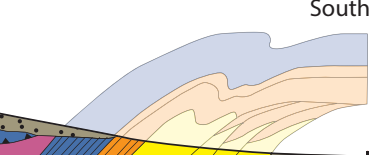

South

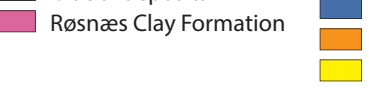

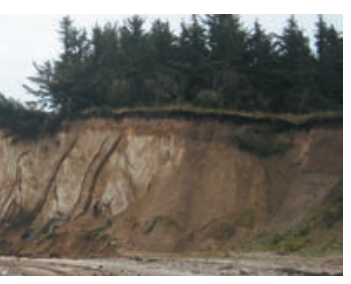

ant

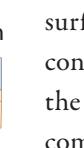
ase and the glaciotectonic unthe thrust complex into thrust-sheet segments. 3. Third order surfaces, the fold structures. To illustrate the typical third-order surfaces the hanging-wall anticlines have been extended above ground. Fourth-order surfaces are too small to be illustrated, but are documented in Pedersen (2014). The imbricate duplexes in the southern part of the complex are also seen in $\mathbf{B}$. orientation of their axial surface, the angle of their limbs and the inclination of their fold axes.

Fourth-order surfaces include all small-scale structures such as faults with small displacements; such faults are important for the understanding of the dynamic development. Joints and anastomosing joints indicate early deformation impact, and the zone axis of conjugate faults indicates the direction of compaction. The asymmetry of small- and mesoscale folds and the sense of displacement on faults as indicated by groove marks can be used to reconstruct the kinematics of deformation.

For the macro-scale identification of the head and tail of glaciotectonic complexes, a distal, a central and a proximal domain are defined. The domain nearest to the foreland (the head end) is regarded as the distal part, which is commonly limited by the trace of the last thrust fault displaced towards the undeformed foreland (the tipline). The central domain displays the bulk architecture of the complex. The proximal domain comprises the deepest level of deformation with the most complicated structural relationships, potentially including superimposed deformation and mud diapirism. Situated at the tail end, the proximal domain is delimited by the contact to the hinterland of the complex. For glaciotectonic complexes, the hinterland contact is the boundary between the hill and the hole in a 'hill/hole pair'. At the time of dislocation, it formed the contact between the pushing ice and the dislocated geological units.

\section{The distal domain}

In the distal part of a glaciotectonic complex, the dip of the thrust fault ramps is gentle and the thrust fault flats are almost horizontal (Fig. 3). The thrust sheets are thinner than in the central domain, which is a consequence of the décollement surface that rises from the deepest level in the trailing end to the topographic surface in the foreland. One of the most surprising features of distal thrust sheets is their length. In the seismic section from the Jammerbugt Glaciotectonic Complex the length of a thrust sheet exceeds $1 \mathrm{~km}$, and the thrust sheets in the northern part of Møns Klint are more than $500 \mathrm{~m}$ long (Fig. 3). Such long thrust sheets are surprising when their thickness is taken into account. At Møns Klint the chalk sheets in the distal part of the glaciotectonic structure are only c. $25 \mathrm{~m}$ thick and one would expect that the forces pushing the thrust sheets would break them up into fragments. The explanation for this missing fragmentation is that high porewater pressure along the thrust faults carries the unbroken thrust sheets.

\section{The central domain}

When a long and relatively thin thrust sheet is created in the distal part of a complex it is easy to understand that, when the thrusting propagates, the distal domain will move to the central domain during the formation of a new distal domain next to the foreland. Two marked types of structures may form during this development: (1) the thrust sheets are broken into shorter segments creating imbricate fans along steeper-dipping thrust faults (Pedersen 2005), or (2) super- 

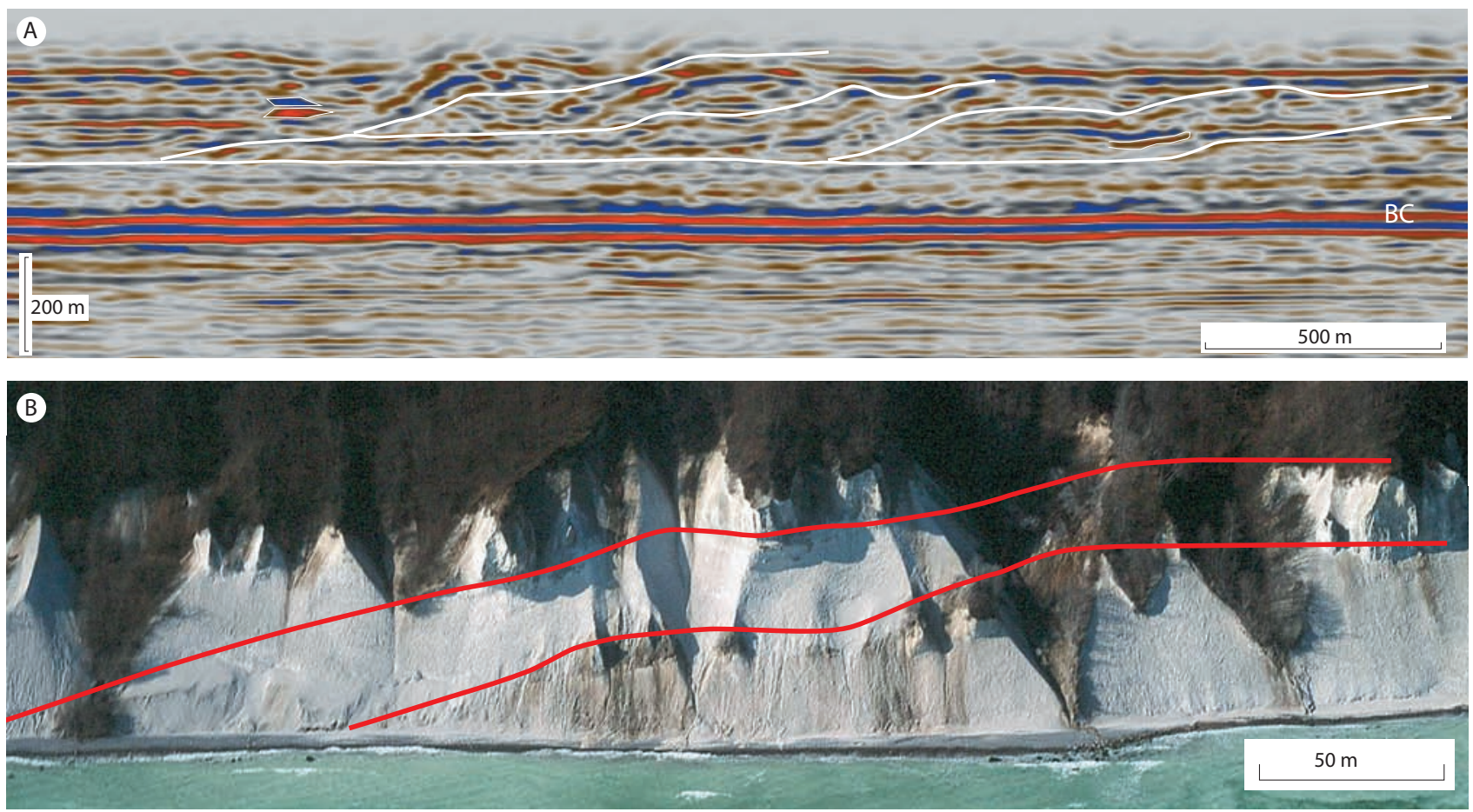

Fig. 3. Thrust-fault architecture in the distal domains of two complexes. A: Seismic section from the Jammerbugt Glaciotectonic Complex. The strong reflectors are interpreted as the base of the Chalk Group (BC) in the North Sea. This implies that the main parts of the thrust sheets comprise Upper Cretaceous chalk. B: Thin, gently dipping thrust sheets in the northern part of Møns Klint. The chalk at Møns Klint is of Maastrichtian age.

posed thrust sheets are displaced together and passing over new, more deeply seated ramps. During this translation an antiformal stack is created, which is the explanation for the impressive structure at Dronningestolen at Møns Klint (Pedersen 2000, 2014; Pedersen \& Gravesen 2009). A similar structure has been identified in a seismic section from the central domain of the Jammerbugt Glaciotectonic Complex.

\section{The proximal domain}

The proximal part of a thin-skinned thrust-fault complex is characterised by an increasing number of thrust fault ramps and flats, imbricate thrust sheets and duplex segments (Pedersen 2005). In Fig. 4 this is illustrated by a section from the proximal part of the Jammerbugt Glaciotectonic Complex and the southernmost imbricate thrust sheets at Møns Klint. The thrust sheets at Møns Klint are $c .60 \mathrm{~m}$ thick, and the dips of the thrust faults are close to the maximum angle of fracturing $\left(<45^{\circ}\right)$. The thrusting probably includes superimposed tilting on deeper thrust faults below sea level. According to Surlyk (1984) the stratigraphic level of the Maastrichtian chalk is lower in the thrust sheets shown in Fig. 4 than the chalk exposed in the distal domain in Fig. 3. Thus the thrusting and hence also the position of the décollement surface have shifted to a deeper level in the proximal domain. This relationship is also seen in the thrust-fault architecture of the seismic section from Jammerbugten (Fig. 4). In the distal and central domains the décollement surface is situated above the base of the Chalk Group (BC in Fig. 4). In the proximal domain, the décollement surface drops down to the lower part of the marked reflectors representing the base of the Chalk Group. The marked BC reflectors are present in the thrust sheets of the tailing part of the proximal domain. The thrust sheets in the Jammerbugt Complex are about twice as thick as the thrust sheets at Møns Klint. This reflects that at Møns Klint only the frontal parts of the wedge-shaped thrust sheets are exposed, whereas in the seismic section the deeper, thicker parts of the thrust sheets can be recognised.

\section{Conclusion}

The architecture of thin-skinned thrust-fault deformation is described on the basis of three glaciotectonic complexes. The thrust-fault architecture of thrust-fault belts and of glaciotectonic complexes is fairly similar even though the former are related to compressional regimes in plate-tectonic settings, the latter to compression caused by gravitational expansion of ice sheets. Glaciotectonic thrust-fault complexes are divided into proximal (nearest to the source of force), 

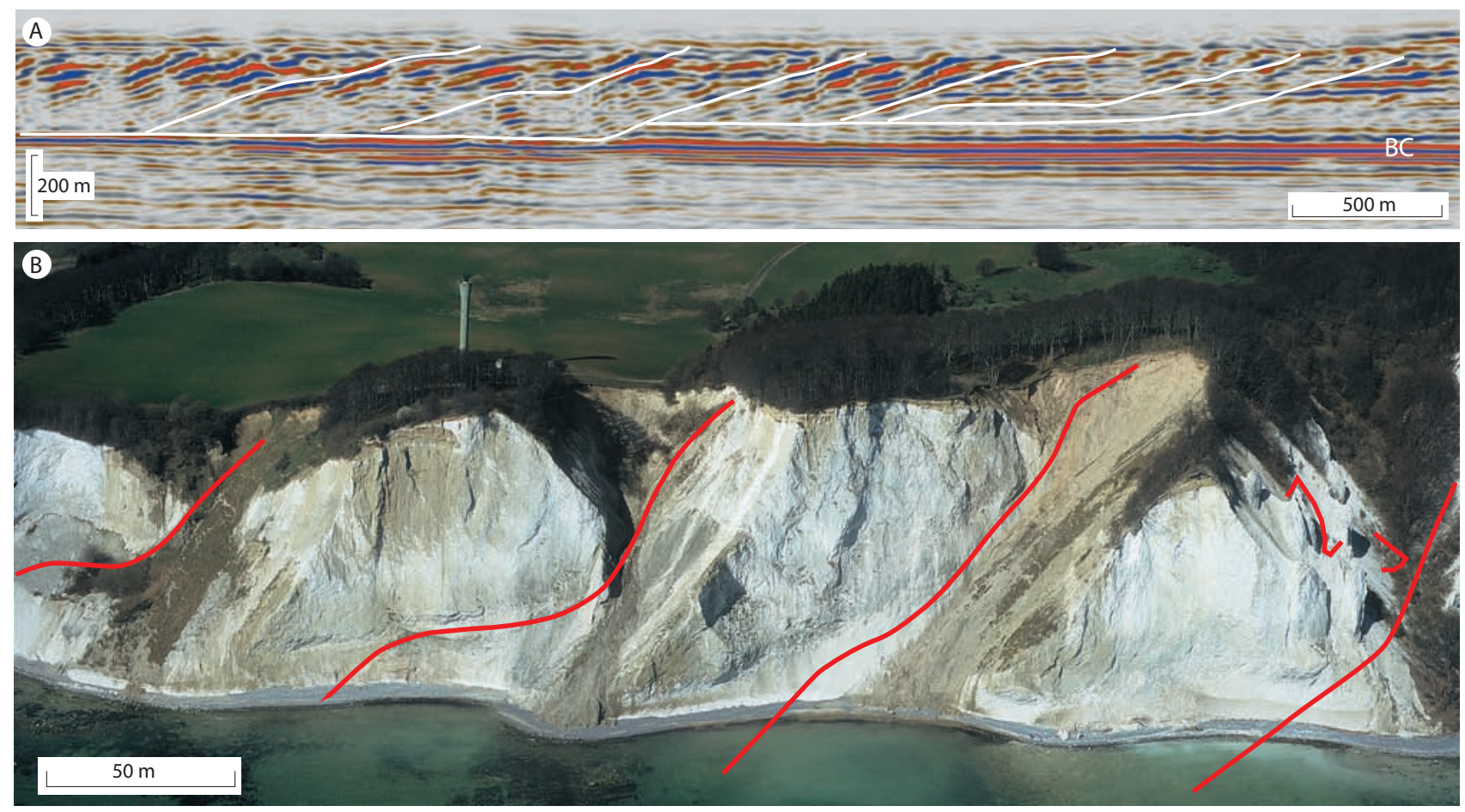

Fig. 4. Two examples showing thrust-fault architecture in the proximal parts of glaciotectonic complexes. A: Seismic section from the Jammerbugt Glaciotectonic Complex. The décollement surface is stepping down to the lower part of the marked reflectors that represent the base of the Chalk Group (BC). B: The oldest chalk (Surlyk 1984) at Møns Klint is found in the centre of the photograph, which shows the southernmost imbricate thrust sheets in the Møns Klint Glaciotectonic Complex.

central and distal domains (farthest away from the source of force). The distal domain includes the foreland boundary of the thrust-fault complex, and it is characterised by long and thin, gently dipping thrust sheets. The central domain is characterised by sequentially superimposed folding of thrust sheets formed in the distal domain. Imbricate thrustfault segments are formed when the sheets break. The proximal domain is characterised by the shift of the décollement surface down to the deepest level, thicker thrust sheets and stacking of thrust-fault duplexes.

\section{References}

Brookfield, M.E. 1977: The origin of bounding surfaces in ancient aeolian sandstones. Sedimentology 24, 303-332.

Miall, A.D. 1985: Architectural-element analysis: a new method of facies analysis applied to fluvial deposits. Earth-Science Reviews 22, 261-308.

Pedersen, S.A.S. 2000: Superimposed deformation in glaciotectonics. Bulletin of the Geological Society of Denmark 46, 125-144.

Pedersen, S.A.S. 2005: Structural analysis of the Rubjerg Knude Glaciotectonic Complex, Vendsyssel, northern Denmark. Geological Survey of Denmark and Greenland Bulletin 8, 192 pp.

Pedersen, S.A.S. 2014: Architecture of glaciotectonic complexes. Geosciences 4, 269-296.

Pedersen, S.A.S. \& Gravesen, P. 2009: Structural development of Maglevandsfald: a key to understanding the glaciotectonic architecture of Møns Klint, SE Denmark. Geological Survey of Denmark and Greenland Bulletin 17, 29-32.

Surlyk, F. 1984: The Maastrichtian Stage in NW Europe, and its brachiopod zonation. Bulletin of the Geological Society of Denmark 33, 217-223.

\section{Author's addresses}

S.A.S.P., Geological Survey of Denmark and Greenland, Øster Voldgade 10, DK-1350 Copenhagen K, Denmark. E-mail: sasp@geus.dk

L.O.B., Department of Geosciences and Natural Resource Management, University of Copenhagen, Øster Voldgade 10, DK-1350 Copenhagen K, Denmark. 